\title{
PENGGUNAAN PENANDA MOLEKULER RANDOM AMPLIFIED POLYMORPHIC DNA (RAPD) UNTUK ANALISIS KERAGAMAN GENETIK KELAPA WEST AFRICAN TALL (WAT)
}

\author{
Edy F. Lengkong ${ }^{1}$ dan S.D. Runtunuwu ${ }^{1,2}$
}

\begin{abstract}
Lengkong, E.F. and S.D. Runtunuwu. 2005. Use of Molecular Marker Random Amplified Polymorphic DNA (RAPD) to Genetic Diversity analysis of West African Tall (WAT) Coconut. Eugenia 11 (3) : 210-217.

Information on genetic diversity of crop germplasm has several important implications for plant breeder. Among others is to help the breeders to decide what sources to cross so as to making new genetic combination. The Use of molecular marker to genetic diversity analysis on DNA level is usefull, because it provides an opportunity to more precisely measure genetic relationships as well as is not affected by the environment. The objective of this research was to analyze genetic diversity of West African Tall (WAT) using molecular marker RAPD. Five abritrary 10 -mer primers were used to amplify total DNA genom, and to generate 44 band DNA with 26 band or $59 \%$ were polymorphic band. It was revealed that genetic diversity within population of WAT cococnut was $14 \%$. Based on cluster analysis, at the genetic similarity $85 \%$ or genetic diversity $15 \%$ the population was separated on three clusters. This research concluded that the population of WAT coconut grown from open pollinated seeds has different genotype one each others.
\end{abstract}

Keywords : West African Tall (WAT), Coconut, RAPD

\section{PENDAHULUAN}

Program pemuliaan kelapa di Indonesia bertujuan menghasilkan kelapa yang mempunyai karakteristik antara lain berbunga cepat, habitat pohon pendek, resisten terhadap hama dan penyakit, hasil kopra persatuan areal tinggi dengan pemupukan rendah, ukuran buah besar, daging buah tebal, kandungan minyak tinggi, dan kandungan air rendah. (Rompas, Luntungan, dan Novarianto 1988).

Permasalahan pemuliaan kelapa di Indonesia saat ini adalah walaupun tersedia cukup banyak tanaman calon tetua potensial, namun informasi tentang keragaman genetika pada umumnya belum cukup tersedia. Selain masalah tersebut, kegiatan pemuliaan kelapa yang dilakukan saat ini membutuhkan waktu yang cukup lama (sekitar 7-8 tahun) baru dapat diketahui hasil dari suatu persilangan yang telah dilakukan.

Kelapa WAT (West African Tall) merupakan salah satu tetua jantan potensial untuk program pemuliaan kelapa, berasal dari Pantai Gading dan merupakan tetua jantan dari kelapa hibrida PB121 (MYD/GKN x WAT), sifatnya berproduksi tinggi, kandungan minyak tinggi, buah besar tetapi tidak tahan terhadap penyakit busuk pucuk

Informasi tentang keragaman genetika plasma nutfah tanaman memiliki beberapa fungsi penting yang dapat dimanfaatkan pemulia tanaman dalam pengembangan tanaman unggul. Penentuan hubu-

\footnotetext{
1 Lab. Genetika dan Pemuliaan Tanaman Fakultas Pertanian UNSRAT Manado, 95115

${ }^{2}$ Lab. Fisiologi Tanaman Fakultas Pertanian UNSRAT Manado, 95115
} 
ngan genetika dari sumber plasma nutfah spesifik juga sangat berguna untuk menentukan galur atau populasi mana yang akan dipertahankan untuk memaksimalkan keragaman genetika plasma nutfah (Thormann and Osborn 1992). Informasi yang akurat tersebut tidak dapat diperoleh dengan hanya menggunakan penanda morfologis atau sitologis karena kedua penanda jenis ini selain pemanfaatannya terbatas juga memperlihatkan sifat pewarisan yang dominan atau resesif, memiliki tingkat polimorfisme yang sedikit, dan dipengaruhi oleh lingkungan (Aswidinnoor 1991).

Random amplifeid polymorphic DNA (RAPD) merupakan salah satu penanda molekuler yang dapat digunakan untuk mendeteksi keragaman genetika pada tingkat DNA (deoxyribonucleic acio), baik pada daerah penyandi maupun bukan daerah penyandi protein dengan cara mendeteksi sekuens polimorphis dalam rantai nukleotida. RAPD dapat mendeteksi keragaman DNA dari suatu populasi tanaman berdasarkan pada penggandaan DNA secara berantai (polymerase chain reaction, PCR). Penggunaan penanda molekuler RAPD untuk analisis keragaman genetika selain tidak dipengaruhi lingkungan, juga memberikan hasil yang lebih cepat karena dapat mendeteksi hasil persilangan pada saat dini (pada stadia bibit) (Tingey et al. 1992; Sambrook, et al. 1989) sehingga penerapannya pada tanaman tahunan seperti kelapa akan sangat membantu dalam efisiensi waktu terutama untuk mendeteksi hasil suatu persilangan.

Penggunaan penanda molekuler RAPD untuk tujuan pemuliaan tanaman sudah banyak dilaporkan antara lain oleh Lengkong (2001) yang menganalisis keragaman genetika beberapa galur padi gogo. Sriyadi et al. (2002) yang mempelajari hubungan kekerabatan tanaman teh. Sedangkan penggunaan penanda RAPD pada tanaman kelapa mula-mula dilaporkan oleh Assburner et al. 1997 yang meng- $c$ analisis keragaman genetika kelapa yang terdapat di wilayah Pasifik Selatan. Di Indonesia sendiri penelitian penggunaan penanda RAPD untuk analisis keragaman genetika kelapa baru dimulai tahun 1998, seperti yang dilaporkan oleh Lengkong, Hartana dan Suharsono (1998) yang menganalisis keragaman genetika kelapa Genjah Kuning Nias (GKN), Genjah Kunig Bali (GKB) dan Genjah Oranye Sagrat (GOS) yang terdapat di kebun koleksi BALITKA Manado. Runtunuwu dan Lengkong (2005) menggunakan penanda RAPD untuk melihat beberapa hasil persilangan kelapa Genjah Salak (GSK) dengan beberapa Kelapa Dalam dalam hubungannya dengan ketahanan terhadap penyakit gugur buah.

Tujuan penelitian ini adalah menganalisis keragaman genetik kelapa West African Tall (WAT) dengan memanfataan penanda molekular Random Amplified Polymorphic DNA (RAPD).

\section{METODE PENELITIAN}

\section{Bahan dan Cara Kerja}

Bahan tanaman yang dianalisis yaitu kelapa WAT berasal dari kebun PTPN XIV unit Halmahera Utara di Boyong Atas. Dari seluruh populasi dipilih secara acak 30 pohon sampel. Masing-masing tanaman sampel diambil daunnya yang masih muda (berupa daun tombak/janur) yang akan diisolasi DNAnya untuk analisis RAPD.

Isolasi DNA total tanaman akan dilakukan mengikuti Rohde et al. (1995) dengan beberapa perubahan (Runtunuwu, Hartana dan Suharsono 2002). Daun kelapa muda seberat $1,5 \mathrm{~g}$ akan digerus bersama $10 \mathrm{ml}$ bufer lisis (100 mM Tris $\mathrm{HCl} \mathrm{pH} 8,1,4 \mathrm{M} \mathrm{NaCl}, 20 \mathrm{mM}$ EDTA, $2 \%$ CTAB + 0,2\% $\beta$-merkaptoetanol ditam- 
bahkan pada saat akan digunakan) dan pasir kwarsa $70 \mathrm{mg}$ lalu dimasukkan ke dalam tabung sentrifus $15 \mathrm{ml}$. Setelah diinkubasi selama 90 menit pada $60{ }^{\circ} \mathrm{C}$ larutan yang mengandung DNA dikoleksi dengan disentrifus pada kecepatan 3500 rpm selama 15 menit lalu diekstraksi dengan kloroform. Selanjutnya DNA dipresipitasi dengan menambahkan 0,8 volume isopropanol lalu diendapkan dengan disentrifus pada kecepatan $3500 \mathrm{rpm}$ selama 15 menit. DNA dikeringkan dan dilarutkan dalam $100 \mu \mathrm{l}$ akuabides steril. Konsentrasi DNA ditentukan berdasarkan nilai absorbansi $A_{260}$, nilai $A_{260}=$ setara dengan $50 \mu \mathrm{g}$ DNA/ml. Sedangkan kemurniannya ditentukan berdasarkan perbandingan nilai absorbansi $A_{260} / A_{280}$. DNA yang murni mempunyai perbandingan $A_{260} / A_{280}=1,8-2,0$ (Sambrook et al. 1989).

Amplifikasi (penggandaan) PCR DNA dilakukan menggunakan mesin Thermocycler Gene Amp PCR System 2700 (Applied Biosystem). Primer yang di- gunakan untuk proses amplifikasi PCR adalah sebanyak 5 jenis primer acak 10mer (Operon Technologies, Alameda California), untuk masing-masing DNA sampel. Adapun komposisi dari volume reaksi PCR sebanyak $50 \mu$, yang mengandung: bufer PCR, $200 \mu \mathrm{M}$ dNTP (dATP, dGTP, dCTP, dan dTTP), 2,5 mM $\mathrm{MgCl}_{2}, 1$ u Taq DNA polimerase (Pharmacia), 5 pmol primer, dan $50 \mathrm{ng}$ DNA cetakan. Kondisi amplifikasi PCR yang akan digunakan adalah : (1). Pra-PCR $95^{\circ} \mathrm{C} / 5$ menit, (2). Denaturasi $95^{\circ} \mathrm{C} / 1$ menit, (3). Pelekatan primer $37^{\circ} \mathrm{C} / 1$ menit, (4). Pemanjangan DNA $72^{\circ} \mathrm{C} / 2$ menit), dan Pasca-PCR $72^{\circ} \mathrm{C} / 5$ menit). Tahap $2-4$ dilakukan sebanyak 35 siklus ( Lengkong et al. 2001). Hasil amplifikasi $P C R$ akan dielektroforesis pada $75 \mathrm{~V}$ selama 2 jam 30 menit dalam $1 \%$ gel agarosa lalu diwarnai dengan etidium bromida. Polimorfisme pita DNA hasil amplifikasi PCR akan diamati dan akan didokumentasi di atas lampu UV.

Tabel 1. Primer yang Digunakan dan Sekuens Nukleotidanya (Primers Were Used and Its Nucleotide Sequence)

\begin{tabular}{|c|c|c|}
\hline No. & Primer & Sekuens $\left(5^{\prime}-3^{\prime}\right)$ \\
\hline 1. & OPA-04 & AATCGGGCTG \\
\hline 2. & OPA-09 & GGGTAACGCC \\
\hline 3. & OPA-15 & TTCCGAACCC \\
\hline 4. & OPA-18 & AGGTGACCGT \\
\hline 5. & OPB-07 & GGTGACGCAG \\
\hline
\end{tabular}

Analisis data dilakukan dengan cara pola pita DNA setiap tanaman kelapa untuk setiap primer hasil elektroforesis pada gel agarose diinterpretasi datanya berdasarkan pita DNA yang dihasilkan. Setiap pita dianggap sebagai satu karakter, dan dinilai ' 1 ' bila ada pita dan ' 0 ' bila tidak ada pita yang terlihat. Berdasarkan atas ada atau tidak adanya pita DNA tersebut, disusun matriks data biner untuk semua primer, kemudian diturunkan matriks jarak kesamaan genetika antar individu tanaman dengan menggunakan koefisien kesamaan Jaccard, dengan persamaan :

$$
\mathrm{S}_{\mathrm{rs}}=\frac{A}{A+B+C}
$$

Dimana :

$S_{\text {rs }}$ : Nilai kesamaan genetika antara individu tanaman $r$ dan individu tanaman s 
A : Jumlah pita DNA yang terdapat baik pada individu tanaman $\mathbf{r}$ maupun individu tanaman $\mathbf{s}$

$B$ : Jumlah pita DNA yang hanya terdapat pada individu tanaman $\mathbf{s}$

C : Jumlah pita DNA yang hanya terdapat pada individu tanaman $\mathbf{r}$

Data jarak genetika antar masingmasing individu tanaman ini selanjutnya digunakan untuk analisis pengelompokan secara sequential agglomerative, hierarchical and nested clustering (SAHN) menggunakan metode UPGMA (unweighted pair-group method arithmatic) dan dibentuk dendrogram untuk melihat hubungan antar individu satu dengan individu lainnya. Keseluruhan analisis data ini dikerjakan melalui program komputer Numerical Taxonomy System (NTSYS-pc) versi 1.70 .

\section{HASIL DAN PEMBAHASAN}

\section{Profil Pita DNA Hasil Amplifikasi}

Hasil amplifikasi PCR dengan menggunakan 5 jenis primer random menunjukkan masing-masing primer memberikan hasil penggandaan/amplifikasi pita DNA dengan polimorhisme yang beragam. Adapun ukuran pita DNA yang dihasilkan berukuran antara 150-3050 bp, dan memiliki resolusi yang berbeda-beda yaitu dari yang sangat jelas dan tebal sampai yang suram dan tipis.

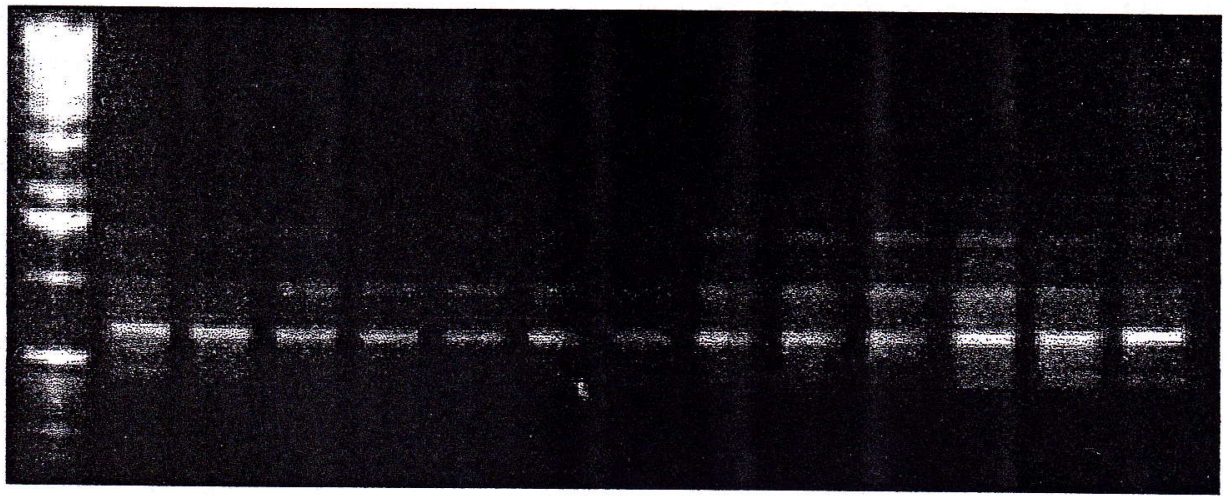

Gambar 1. Profil Pola Pita DNA Kelapa WAT Hasil Amplifikasi PCR Menggunakan Primer OPB-07. Lajur 1 adalah Penanda DNA 1 kb Ladder, sedangkan Lajur 2-14 merupakan Sampel Kelapa WAT nomor 14-26. (Banding Patterns DNA Profile of WAT Cococnut Amplified by OPB-07 Primer. Lane 1 was Ladder DNA Marker, Lane 2-14 Were the Sample Tree no. 1-13 of WAT Coconut, Respectively)

Hasil amplifikasi PCR pada Tabel 2 menunjukkan bahwa pada kelapa WAT dengan menggunakan 5 jenis primer random dapat diamplifikasi 44 pita DNA dengan jumlah pita polimorphis sebanyak 26 pita atau sebesar $59 \%$. Jumlah pita polimorphis dalam analisis keragaman genetik sangat berpengaruh dalam penentuan tingkat keragaman suatu populasi, karena banyaknya pita polimorphis akan lebih dapat menggambarkan keadaan genom tanaman dan akan memperkecil bias yang disebabkan tidak terwakilinya bagian-bagian genom (Neinhuis et al. 1994). Perbedaan jumlah dan polimophis pita DNA yang dihasilkan setiap primer menggambarkan kekompleksan dari genom yang diamati (Grattapaglia et. al. 1992). 
Tabel 2. Primer dan Jumlah Pita DNA yang Diamplifikasi (Primer and Number of DNA Bands that Amplified)

\begin{tabular}{|l|l|c|c|}
\hline \multirow{2}{*}{ No. } & \multirow{2}{*}{ Primer } & \multicolumn{2}{|c|}{ WAT } \\
\cline { 3 - 4 } & & Jumlah pita & Pita polimorphis \\
\hline 1. & OPA-04 & 9 & 5 \\
\hline 2. & OPA-09 & 9 & 6 \\
\hline 3. & OPA-15 & 9 & 5 \\
\hline 4. & OPA-18 & 9 & 6 \\
\hline 5. & OPB-07 & 8 & 4 \\
\hline \multicolumn{2}{|c|}{ Total } & 44 & 26 \\
\hline
\end{tabular}

\section{Keragaman Genetik Kelapa West African Tall (WAT)}

Keragaman genetik populasi kelapa WAT ditentukan berdasarkan hubungan kesamaan genetik antara satu individu tanaman dengan tanaman kelapa yang lain dengan cara membandingkan pola pita DNA yang dihasilkan dari amplifikasi PCR menggunakan koefisien kesamaan jarak Jaccard. Hasil analisis kesamaan genetik menunjukkan bahwa kelapa WAT memiliki kesamaan genetik sebesar $86 \%$ atau keragaman genetik dalam populasi sebesar $14 \%$. Keragaman tertinggi ( $28 \%$ ) dijumpai antara individu WAT2 dan WAT27 sedangkan yang terendah (0\%) dijumpai antara individu WAT 19 dan 21.

Keragaman genetik sebesar $14 \%$ dari ke 30 kelapa WAT yang dianalisis tersebut menunjukkan bahwa populasi kelapa WAT yang ditanam di kebun PTPN XIV unit Halmahera Utara di Boyong Atas berasal dari benih hasil dari persilangan alami dengan status genotip yang tidak homogen. Hal ini disebabkan tanaman kelapa memiliki empat pola penyerbukan yaitu : alogami sempurna, autogami langsung, autogami semi langsung dan autogami tak langsung (Rognon 1976). Dengan penyerbukan seperti ini sangat memungkinkan terjadinya penyerbukan silang baik antar pohon dalam satu kultivar, ataupun antar tanaman kelapa kultivar berbeda. Akibat sistem penyerbukan se- perti ini, maka buah kelapa yang dihasilkan baik dari satu manggar ataupun berlainan manggar dalam satu pohon sulit dipastikan genotipenya.

Analisis pengelompokkan seperti yang terlihat pada dendrogram (Gambar 2) yang diturunkan dari matriks kesamaan pada kelapa WAT menunjukkan bahwa pada tingkat kesamaan genetik $85 \%$ atau keragaman $15 \%$, maka populasi kelapa terbagi atas 3 kelompok utama yaitu, kelompok I terdiri atas 8 tanaman (WAT 1, WAT4, WAT6, WAT2, WAT7, WAT9, WAT10, WAT8), kelompok $\|$ terdiri atas 20 tanaman (WAT3, WAT26, WAT16, WAT13, WAT14, WAT27, WAT11, WAT12, WAT19, WAT21, WAT20, WAT22, WAT28, WAT29, WAT18, WAT30, WAT17, WAT23, WAT24, dan WAT25), dan kelompok III terdiri atas 2 tanaman (WAT5 dan WAT15).

Pengelompokan diatas didasarkan atas kesamaan yang dimiliki oleh masingmasing individu, sehingga individu-individu kelapa yang berada dalam satu kelompok secara langsung memiliki tingkat kesamaan genetik yang relatif sama dibandingkan dengan individu-individu kelapa yang ada dalam kelompok lainnya. Setiap kelompok individu tersebut selanjutnya dapat mewakili satu kelompok genetik tertentu. 


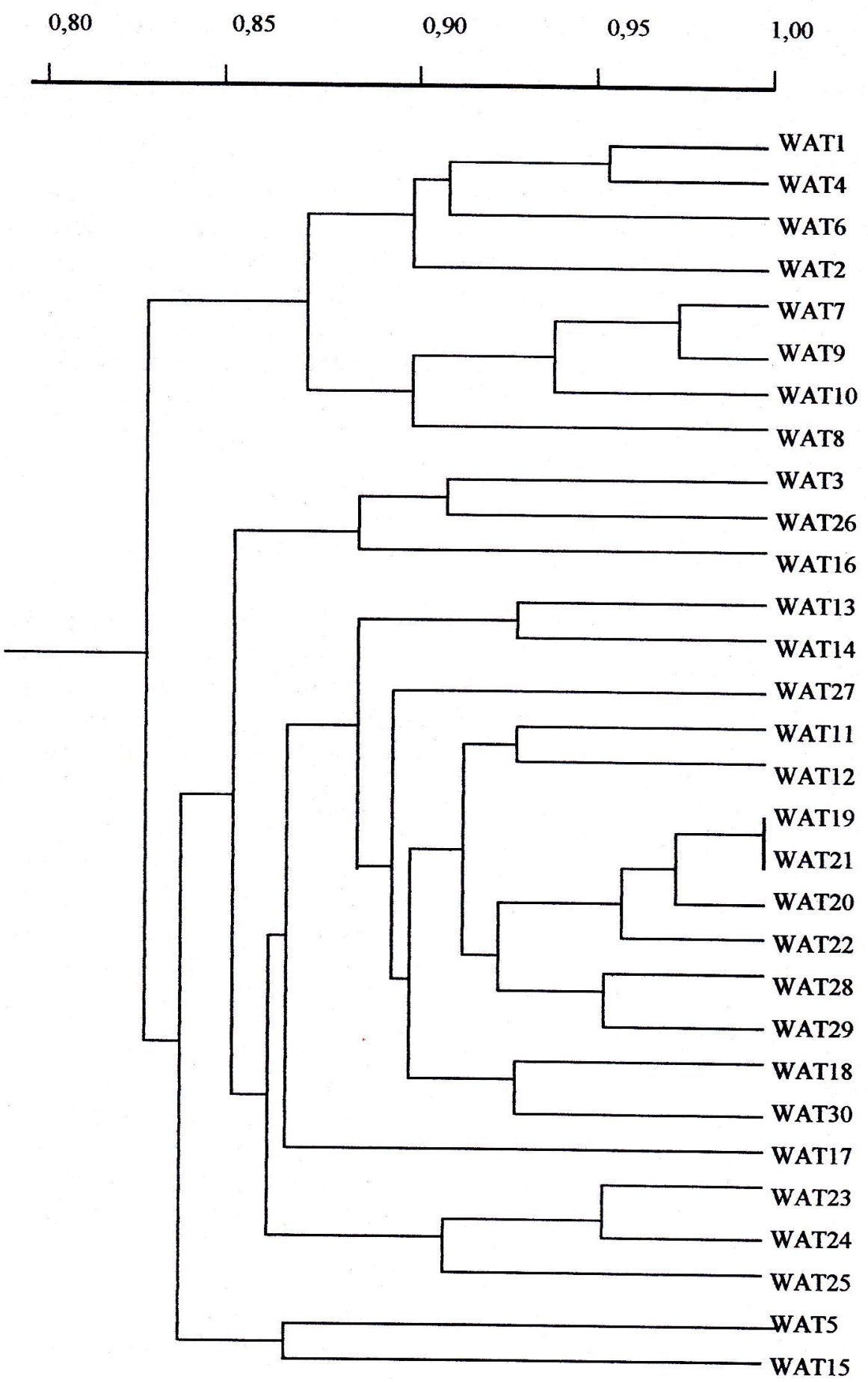

Gambar 2. Dendrogram Kelapa West African Tall (WAT) (Dendrogram of West African Tall WAT Coconut) 
Implikasi dari hasil pengelompokan tersebut untuk program pemuliaan kelapa khususnya bila kelapa WAT tersebut akan digunakan sebagai tetua jantan untuk persilangan adalah dengan memperlakukan masing-masing tanaman sebagai individu yang berbeda genotipenya sehingga serbuksari dari populasi kelapa WAT tidak dapat di bulk atau digabung satu dengan yang lainnya. Kalaupun kondisinya tidak memungkinkan karena dibutuhkan jumlah serbuksari yang cukup banyak, maka penggabungan serbuksari disarankan hanya dapat dilakukan antara individu-individu pohon yang terdapat dalam satu kelompok saja.

\section{KESIMPULAN}

1. Keragaman genetik populasi kelapa WAT sebesar $14 \%$

2. Populasi kelapa WAT yang dianalisis berasal dari benih hasil penyerbukan terbuka dimana setiap individu kelapa memiliki genotipe yang berbeda satu dengan lainnya.

\section{UCAPAN TERIMA KASIH}

Penelitian ini merupakan sebagian dari penelitian yang dibiayai oleh Riset Pengembangan Kapasitas (RPK) tahun 2003 No. Kontrak 04/02/SK/RPK/2003.

\section{DAFTAR PUSTAKA}

Ashburner, R.G., W.K. Thomson, and G.M. Halloran. 1997. RAPD Analysis of South Pacific Coconut Palm Populaton. Crop Sci. 37:992-997

Aswidinnoor, H. 1991. Rekayasa Genetika, p. 96-186. Dalam S. Harran dan N. Ansory (ed). Bioteknologi
Pertanian II. Pusat Antar Universitas (PAU) Bioteknologi, IPB-Bogor.

Grattapaglia, D., J. Chaparro, P. Wilcox, S. McCord, D. Werner, $H$. Amerson, S. McKeand, F. Bridgwater, R. Whetten, D. O'Malley, and R. Sederoff. 1992. Mapping in woody plants with RAPD markers: application to breeding in forestry and horticulture, p. 37-40. In Application of RAPD Technology to Plant Breeding. Joint Plant Breeding symposia Series, Minneapolis, Minnesota.

Lengkong, E. F., A. Hartana dan Suharsono. 1998. Keragaman Genetika Beberapa Kultivar Kelapa Genjah Berdasarkan Penanda Random Amplified Polymorphic DNA (RAPD). Prosiding Hasil Penelitian Bidang IImu Hayat. IPB. Bogor 123:1-12.

E.F. 2001. Keragaman Genetika Beberapa Galur Padi Gogo Berdasarkan Penanda Molekuler Random Amplified Polymorphic DNA (RAPD). Eugenia 7 (4) : 201207.

E.F., Suharsono, D.D. Runtunuwu dan A. Hartana. 2001. Pengoptimum reaksi berantai polimerase DNA tanaman kelapa. Hayati 8 (4) :121-123

Nienhuis, J., J. Tivang, and P. Skroch. 1994. Analysis of genetic relationship among genotypes based on molecular marker data, p. 8-14. In Analysis of Malecular Marker Data. Joint Plant Breeding Symposia Series, Corvalis, 
Rognon, F. 1976. Floral biology of coconut duration and sequence of male and female phase in various types of coconut. Oleagineux 31:13-17.

Rohde, W., A. Kullaya, J. Rodriquez, and E. Ritter. 1995. Genome analysis of Cocos nucifera L. by PCR amplification of spacer sequences separating a subset of copia-like EcoRI repetitive elements. J. Genet. Breed. 49:179-186.

Rompas, T., H.T. Luntungan, dan h. Novarianto. 1988. Metoda Pemuliaan Kelapa. Hal. 27-39. dalam Prosiding Simposium I Hasil Penelitian dan Pengembangan Tanaman Industri, Buku II. Kelapa I. Puslitbangtri, Bogor.

Runtunuwu, D.S., A. Hartana, Suharsono. 2002. Teknik RAPD dengan metode ekstraksi DNA dan kit PCR yang berbeda. Hayati $9(3)$ : 9496.

Runtunuwu, S.D. dan E. Lengkong. 2005. Identifikasi Penanda Izozim PER7, PER-8, dan RAPD OB17 375 pada Kelapa Genjah Salak (GSK) dan Beberapa Hasil Silangannya dengan Kelapa Dalam. Eugenia 11 (1): 8-17
Sambrook, J., E.F. Fritsch, and T. Maniatis. 1989. Molecular cloning. A laboratory manual. Cold Spring Harbor Lab. CSH, New York.

Sriyadi, B., R. Setiamihardja, A. Baihaki, dan W. Astika. 2002. Hubungan Kekerabatan Genetik antar Tanaman the F1 Dari Persilangan Tri 2024 x PS 1 Berdasarkan Penanda RAPD. Zuriat 7 (1) : $11-20$

Thormann, C.E. and T.C. Osborn. 1992. Use of RAPD and RFLP markers for germplasm evaluation. p. 9-11. In Applications of RAPD Technology to Plant Breeding. Joint Plant Breeding Symposia Series, Minneapolis, Minnesota. 1 November 1992. CSSA, Am Soc. Horticul. Sci., and Am. Genet. Assoc.

Tingey, S.V., J.A. Rafalski, and J.G.K. Williams. 1992 Genetic analysis with RAPD markers, p.3-8. In Application of RAPD technology to plant breeding. Joint Plant Breeding Symposia Series, Minneapolis, Minnesota. 